Lars Jockheck

\title{
Od agenta do kolaboranta? Współpraca żydowskiego publicysty Fritza Seiftera z Bielska z władzami niemieckimi w latach trzydziestych i czterdziestych*
}

W połowie lipca 1940 roku w „Krakauer Zeitung” („Gazeta Krakowska”) zamieszczono krótką, ale wzbudzającą sensację informację. W swoim organie prasowym władze okupacyjne Generalnego Gubernatorstwa (części obszaru Polski niewłączonego do Rzeszy, ale oddanego pod niemiecki zarząd cywilny ${ }^{1}$ ) poinformowały, że niedługo ma się w Krakowie pojawić „żydowska gazeta, która będzie przeznaczona dla Żydów z całego Generalnego Gubernatorstwa” ${ }^{2}$. Ludwik Landau, ekonomista żydowskiego pochodzenia pracujący dla polskiego podziemia, zauważył w swojej codziennie pisanej kronice: „Wydanie takiej gazety, może z zakazem dla Żydów kupowania innych gazet, ma stworzyć coś w rodzaju kulturalnego ghetta, być jeszcze jedną przegrodą, a zarazem dowodem normalności stosunków, nawet wśród Żydów, pod rządami niemieckimi”3. Kilka dni później Landau dodał, że redaktorem nowej gazety jest rzekomo „od dawna będący na usługach niemieckich dziennikarz Seifter” - miał na myśli pochodzącego z zachodniej Galicji żydowskiego publicystę Fritza Seiftera, którego władze okupacyjne mianowały nie tylko redaktorem naczelnym, ale także kierownikiem ich „Gazety Żydowskiej”.

* Pierwotna wersja tego artykułu: Vom Agenten zum Kollaborateur? Die Zusammenarbeit des jüdischen Publizisten Fritz Seifter aus Bielitz mit deutschen Behörden in den 1930er und 1940er Jahren, w: J. Tauber (red.), „Kollaboration” in Nordosteuropa. Erscheinungsformen und Deutungen im 20. Jahrhundert, Wiesbaden 2006, s. 192-205.

${ }^{1}$ Stan badań nad okupacją niemiecką w Polsce zob. H.-J. Bömelburg, B. Musial, Die deutsche Besatzungspolitik in Polen 1939-1945, w: W. Borodziej, K. Ziemer (red.), Deutsch-polnische Beziehungen 1939-1945-1949. Eine Einführung, Osnabrück 2000, s. 43-111.

${ }^{2}$ Eine jüdische Zeitung im Generalgouvernement, „Krakauer Zeitung”, 17 lipca 1940, nr 167, s. 6. Informacja ta odnosiła się do rozpowszechnianej w tym samym czasie ulotki reklamowej tej nowo powstającej gazety.

${ }^{3}$ L. Landau, Kronika lat wojny i okupacji, t. 1: Wrzesien 1939 - listopad 1940, Warszawa 1962, s. 589 (wpis z 17 lipca 1940). Landau był pracownikiem Biura Informacji i Propagandy Komendy Głównej AK, zob. G. Mazur, Biuro Informacji i Propagandy SZP-ZWZ-AK 1939-1945, Warszawa 1987, tu: s. 33 i 78). Głębsza analiza powstawania tego zapisu zob. J. Leociak, Sztuka czytania gazet. Legalna prasa okupacyjna: Landau i Jakub, „Teksty drugie” 1998, nr 9, s. 173-198.

${ }^{4}$ L. Landau, op. cit., s. 613 (wpis z 30 lipca 1940). 
Wobec ludobójstwa dokonanego przez Niemców na Żydach zarzut, że niektórzy Żydzi, a przede wszystkim część przedwojennej elity żydowskiej, współpracowała z władzą okupacyjną, budził szczególne kontrowersje. W Izraelu stał się on jednym z mitów, na których bazowało państwo żydowskie, które obiecywało swoim obywatelom, że odtąd będzie bezkompromisowo reprezentować interesy życiowe Żydów. Jednocześnie zarzut ten stał się impulsem, by prócz kultywowania pamięci o Szoa, prowadzić także badania naukowe nad Zagładą i dzięki temu zyskać gruntowną wiedzę na temat relacji Żydów z niemieckimi władzami okupacyjnymi. Pierwsze fundamentalne badania nad zagładą europejskich Żydów Raula Hilberga i ich recepcja przez Hannah Arendt rozpoczęły na przełomie lat 50 . i 60 . burzliwą dyskusję na ten temat ${ }^{5}$. W swoich notkach publicystycznych do procesu Eichmanna Arendt twierdziła, przede wszystkim ze względu na biurokratyczną współpracę pomiędzy Żydami i narodowymi socjalistami: „Rola żydowskich przywódców w zniszczeniu ich własnego narodu jest dla Żydów bez wątpienia najciemniejszą kartą w całej ciemnej historii”. Poza tym wspomniała też żydowską „prasę i wiadomości, które mogły być przez Nazistów kontrolowane i zmieniane”. Chociaż Arendt nazywała takie zachowanie „kooperacją”, jej esej był rozumiany - tak jak wcześniej już tezy Hilberga - jako zarzut powszechnej kolaboracji Żydów z narodowymi socjalistami ${ }^{6}$. Słuszna krytyka, iż Hilberg i Arendt oparli swoje sądy przede wszystkim na dokumentach i wypowiedziach niemieckich, a pominęli perspektywę żydowską, została potraktowana poważnie, a to ze względu na administracyjną współpracę instytucji żydowskich - przede wszystkim utworzonych przez władze okupacyjne Judenratów - z urzędami niemieckimi. Ukazał się przy tym bardziej skomplikowany obraz sytuacji: Żydzi, którzy kontaktowali się z urzędami niemieckimi, przede wszystkim wykonywali rozkazy, ponieważ zakres władzy Niemców i Żydów był nieporównywalny, próbowali jednak wykorzystać w własnym interesie pozostawione im - coraz węższe - pole manewru?

Dużo gorzej zbadana jest prasa, która miała od 1938 roku najpierw w Rzeszy, a następnie na ziemiach okupowanych zastępować gazety żydowskie. Reiner Burger napisał obszerną i szczegółową monografię ukazującej się od przełomu lat 1938 i 1939

${ }^{5}$ R. Stauber, Confronting the Jewish Response During the Holocaust: Yad Vashem - a Commemorative and a Research Institute in the 1950s, „Modern Judaism” 2000, nr 20, s. 277-298; R. J. Cohen, A Generation's Response to Eichmann in Jerusalem, w: Steven E. Aschheim (red.), Hannah Arendt in Jerusalem, Berkeley 2001, s. 253-277, tu s. 253-267; I. Zerkal, Nation und Tod. Der Holocaust in der israelischen Öffentlichkeit, Göttingen 2003, s. 216-227.

${ }^{6}$ H. Arendt, Eichmann in Jerusalem. Ein Bericht von der Banalität des Bösen, wyd. 5, München/Zürich 1986, s. 153 i 161 (Eichmann w Jerozolimie. O banalności zła, Kraków 1987; wydanie amerykańskie 1963). Reakcje na te eseje, zob. H. Mommsen, Hannah Arendt und der Prozess gegen Adolf Eichmann, w: ibidem, s. I-XXXVII, tu s. XXII-XXXII; F. A. Krummacher (red.), Die Kontroverse. Hannah Arendt, Eichmann und die Juden, München 1964 dokumentuje część polemiki z Arendt.

${ }^{7}$ I. Trunk, Judenrat. The Jewish Councils in Eastern Europe under Nazi Occupation, New York 1972. Por. też A. Weiss, Jewish Leadership in Occupied Poland - Postures and Attitudes, „Yad Vashem Studies” 1977, t. 12, s. 335-365; Y. Gutman, C. J. Haft`(red.), Patterns of Jewish Leadership in Nazi Europe 1933-1945, Jerusalem 1979, por. też D. Rabinovici, Instanzen der Ohnmacht. Wien 1938-1945. Der Weg zum Judenrat, Frankfurt am Main 2000, dotyczy prekursorów stworzonych później w obszarach okupowanych Judenratów. 
do 1943 roku najpierw w Berlinie, a później także w Wiedniu „Jüdisches Nachrichtenblatt” („Żydowska Gazeta Informacyjna”), która służyła za wzór dla innych tytułów tworzonych przez Niemców ${ }^{8}$. Burger pisze, że gazeta ta „działała wprawdzie w służbie narodowosocjalistycznej polityki żydowskiej”, odmawia jednak „posądzenia jej twórców o kolaborację". Podkreśla, że Żydzi pod panowaniem narodowych socjalistów znaleźli się w „sytuacji bez wyjścia”, a przede wszystkim, że była, ,jak żadna inna gazeta w III Rzeszy, poddana pełnej kontroli państwa”. Twierdzi, iż sam fakt, że gazeta była robiona „przez Żydów dla Żydów”, dawał redakcji możliwość wypełniania „pewnych społecznych funkcji orientacyjnych". Na taki osąd nie pozwala jednak stan badań nad „Gazetą Żydowską” - ani ze względu na jej pracowników czy treści, ani ze względu na jej funkcję ${ }^{10}$ - chociaż podobnie jak „Jüdisches Nachrichtenblatt” była skierowana do potencjalnie największego kręgu czytelników ${ }^{11}$.

Niewiele wiadomo zwłaszcza na temat życiorysów i motywacji pracowników redakcji i wydawcy „Gazety Żydowskiej”. Ponieważ od początku miała opinię kolaboranckiej, artykuły były podpisywane co najwyżej pseudonimami lub inicjałami ${ }^{12}$.

\footnotetext{
${ }^{8}$ R. Burger, Von Goebbels Gnaden. „Jüdisches Nachrichtenblatt” (1938-1943), Münster 2001.

${ }^{9}$ Ibidem, s. $178 \mathrm{nn}$.
}

${ }^{10}$ Najważniejsze artykuły o „Gazecie Żydowskiej” („GŻ”) napisał Marian Fuks, zob.: Życie w gettach Generalnej Guberni na tle „Gazety Żydowskiej” 1940-1942, „Biuletyn Żydowskiego Instytutu Historycznego" 21, 22 (1971, 1972), nr 79, s. 3-47; nr 80, s. 23-41; nr 81, s. 41-69; Małe Judenraty w świetle „Gazety Żydowskiej” 1940-1942, ibidem, 33 (1983), nr 126/127, s. 169-199; nr 128, s. 99-117; idem, Z dziejów wielkiej katastrofy narodu żydowskiego, Warszawa 1999, s. 103-147, zob. także T. Cieślak, Z historii niemieckiej prasy w języku polskim, „Rocznik Historii Czasopiśmiennictwa” 1968, nr 8, s. 569-588, tu s. 579-588. W roku 1999 na Uniwersytecie Lubelskim im. Marie Skłodowskiej-Curie powstała praca magisterska „Gazeta Żydowska” 1940-1942, której promotorem był Tadeusz Radzik. Nie korzystałem z niej. Barbara Engelking-Boni zapowiedziała pierwszą monografię „Gazety Żydowskiej”, która służyła jej już jako źródło n. t. codzienności getta; por. B. Engelking, J. Leociak, Getto warszawskie. Przewodnik po nieistniejacym mieście, Warszawa 2001.

${ }^{11}$ Według szacunków niemieckich w roku 1940 w Generalnym Gubernatorstwie żyło około 1,7 mln Żydów (zgodnie z kryteriami ustaw norymberskich), co stanowiło 14,2\% ludności, por. H. Gottong, Die Juden im Generalgouvernement, w: „Das Vorfeld” 1940, nr 1 (3), s. 14-20, tu s. 14. R. Burger (op. cit., s. 99 n.) wymienia jako stworzone wzorem „Jüdisches Nachrichtenblatt” jedynie dwujęzyczną „Jüdische Nachrichtenblatt/Židovské listy” z Pragi, „Het Joodsche Weekblad” z Amsterdamu, „Informations Juives” z Paryża oraz w roku 1944 przekształconą w organ informacyjny „Magyar Zsidók Lapja” z Budapesztu, ale nie „GŻ”.

${ }^{12}$ Wyjątkiem jest Marcel Reich (-Ranicki), który informuje w swojej autobiografii, że pisał pod pseudonimem „Wiktor Hart” krytyki muzyczne dla „GŻ”, zob. M. Reich-Ranicki, Mein Leben, Stuttgart 1999, s. 225-230 (Moje życie, Warszawa 2000). Aby wyrobić sobie szerszy pogląd zob. E. Szczepańska-Lange, Sobotnie poranki w Feminie, „Gazeta Wyborcza”, 7 września 2002, nr 209, s. 16 n. Emanuel Ringelblum (Kronika getta warszawskiego. Wrzesień 1939-styczeń 1943, Warszawa 1988, s. 160, 295 i 589 n.) wymienia w swoich zapiskach z żydowskiego podziemia nazwiska domniemanych warszawskich pracowników „GŻ”: docenta judaistyki Edmunda Steina, historyka Majera Bałabana oraz dziennikarzy Hilela Zajdmana, Abrahama (Arona) Mordechaja Rogowoja, Szulima Rozenfelda i Szaula (Szymona) Stupnickiego. Wobec przewodniczącego warszawskiego Judenratu „GŻ” często reprezentował niejaki Langier (Langer), por. M. Fuks (wyd.), Adama Czerniakowa dziennik getta warszawskiego. 6 IX 1939-23 VII 1942, Warszawa 1983, s. 132 i 149 n (wpisy z 22 lipca 1940 i 9-15 września 1940). 
Nawet informacje na temat stojącego najwyżej w hierarchii pracownika, redaktora naczelnego i kierownika „Gazety Żydowskiej” nie wykraczały poza jego nazwisko i pochodzenie. Spróbuję zatem, posługując się kilkoma dokumentami pochodzącymi z akt niemieckich, bliżej naświetlić życiorys i prawdopodobne motywy działania publicysty z Bielska, Fritza Seiftera. Należy przy tym podkreślić, że nieliczne, raczej przypadkowo odnalezione źródła dają tylko fragmentaryczny obraz. Być może w archiwach polskich i izraelskich znajdują się dokumenty, zawierające więcej informacji. Poniższe wywody mają więc być tylko zachętą do dalszych badań.

Fritz Seifter po raz pierwszy zwrócił się do władz niemieckich - do konsulatu generalnego w Katowicach - z propozycją współpracy wiosną 1927 roku. Przedstawił pomysł wydawania niemiecko-żydowskiego dwutygodnika, mającego ukazywać się w Bielsku, na który miał nadzieję otrzymać niemiecką subwencję. Seifter przekonywał władze niemieckie, że z powodu braku jakiegokolwiek organu „dla proniemieckich Żydów z całej Polski”, szczególnie niemiecko-żydowska młodzież „daje się zaciągnąć do obozu żydowsko-narodowego i polsko-żydowskiego". Seifter chciał wydawać czasopismo, które zajmowałoby się przede wszystkim „problemami wewnątrzżydowskimi w przyjaznej Niemcom konwencji” i propagowałoby „konieczność zjednoczenia zorientowanych na zachód Żydów z Niemcami”. Zwracał się tym samym zarówno przeciw „zasymilowanym z Polską Żydom”, jak i „nacjonalistycznym wschodnim Żydom” (miał tu na myśli folkistów z Yiddische Volkspartei) i syjonistom. Powoływał się na niemiecko-żydowskie organizacje działające w Rzeszy, mianowicie na „Centralverein deutscher Staatsbürger jüdischen Glaubens”, „Verband nationaldeutscher Juden” oraz „Jüdisch-liberale Vereinigung für Deutschland”, które rzekomo śledziły jego projekt z ogromnym zainteresowaniem. Aby udowodnić, że jest „niemiecki do szpiku kości”, Seifter wypowiedział się także obszernie na temat swojej biografii.

Friedrich Seifter, który zwykle mówił o sobie „Fritz Seifter”, urodził się 19 listopada 1888 roku w Trzebini, małym miasteczku w zachodniej Galicji, pomiędzy Krakowem a Katowicami. Okres szkolny spędził w pobliskim Bielsku, w austriackiej części Śląska. Po maturze w państwowym Gymnasium (liceum) w roku 1911 udał się do Wiednia, gdzie studiował teologię w szkole rabinackiej i w 1913 roku zdał egzamin na licealnego nauczyciela religii. Jednocześnie, do lata 1915 roku, studiował na wydziale filozofii Uniwersytetu Wiedeńskiego. Po kilku miesiącach służby ze względu na ciężką chorobę został zwolniony z wojska i dzięki temu mógł wiosną 1916 roku zakończyć swoje studia rozprawą doktorską na temat nowożytnej historii Rzeszy, a następnie egzaminem doktorskim. Później pracował jako nauczyciel religii - najpierw przez rok w trzech państwowych szkołach w morawskiej Igławie, a później do listopada 1918 roku w dwóch liceach w Berlinie oraz w szkółce religijnej przy tamtejszej gminie żydowskiej. Po zakończeniu wojny, odebranym przez Seiftera jako „upadek”, jego kariera utknęła w martwym punkcie. Wrócił do Bielska, które teraz było polskim miastem. Przez krótki czas próbował swoich sił jako samodzielny przedsiębiorca (studiował na berlińskim uniwersytecie gospodarkę narodowa), ale na początku lat 20., z powodu kryzysu ekonomicznego, zrezygnował z interesów i zaczął pracować jako wolny dziennikarz gospodarczy dla niemieckojęzycznych gazet w Polsce, Gdańsku, Rzeszy, Austrii i Czechosłowacji. By uniknąć posądzenia, że chce założyć czasopismo dla korzyści 
materialnych, Seifter podkreślał, iż jego zawód zapewnia mu „bogato zabezpieczone i, przede wszystkim, pełne perspektyw rozwoju życie i wysokie dochody”. Poza tym akcentował swój ideowy wkład „dla Niemiec” - w 1923 roku, po napisaniu skierowanego przeciwko Polakom artykułu, został ukarany wysoką grzywną. Ze względu na swoje duże zainteresowanie „zdobyciem Żydów dla Niemców” i „walką przeciwko syjonizmowi i żydowskiemu nacjonalizmowi” byłby również z tej strony często wystawiany na „potężne ataki”"13.

Konsulat Generalny w Katowicach przesłał exposé Seiftera do Urzędu Spraw Zagranicznych w Berlinie. W załączniku konsul Friedrich Illgen wyraził dezaprobatę i dla Seiftera, i dla jego projektu. Pisał, że kręgi niemieckie „bardzo powściągliwie” odnoszą się do tego dziennikarza, ponieważ bywa on często w różnych warszawskich ministerstwach i szerzą się pogłoski, jakoby dostawał „dotacje” od polskiego rządu. Poza tym wskutek „zamkniętego frontu niemieckich Żydów” w żydowskiej gminie Katowice, mimo silnej żydowskiej imigracji ze wschodu, wciąż dominuje element niemiecki. To efekt zręcznej, ustępliwej i wyrozumiałej postawy wobec imigrantów. Konfrontacja, którą chce wywołać Seifter, „według wszelkich przewidywań, nastawiłaby wrogo do Żydów niemieckich dużą część Żydów wschodnich, którzy chwilowo skłaniają się ku kulturze niemieckiej, a przynajmniej nie stoją do niej w opozycji”. Walkę taką Żydzi niemieccy, ze względu na rosnącą liczbę „Żydów wschodnich”, mogliby tylko przegrać14.

Nie da się wywnioskować z akt, czy Urząd Spraw Zagranicznych zareagował na propozycję Seiftera. Dokumentacja została jednak opatrzona klauzulą „Tajne” i najpewniej dołożona do akt osobowych Seiftera (których nie da się już odnaleźć w archiwum Urzędu Spraw Zagranicznych). Te okoliczności wskazują na to, że w Berlinie nie wykluczano współpracy z Seifterem. Jego wizja czasopisma nie została wtedy jednak zrealizowana.

Subwencje przydzielane niemieckiej mniejszości w Polsce, a przede wszystkim prasie, były od dłuższego czasu na porządku dziennym ${ }^{15}$. Jednak ze względu na wzrost antysemityzmu, także wśród Niemców w Polsce, nie było już oczywiste, że niemieckojęzyczni Żydzi będą się utożsamiać z narodem niemieckim. Bielsko jeszcze w czasach austriackich było uważane za „istotne miejsce przemiany Żydów wschodnich w zachod-

${ }^{13}$ Kopia cytowanego tu exposé Seiftera stanowi załącznik do pisma Konsulatu Generalnego w Katowicach, skierowanego do Urzędu Spraw Zagranicznych (USZ) w Berlinie z 14 kwietnia 1927 roku. Archiwum Polityczne Urzędu Spraw Zagranicznych (APUSZ), R 121308, Departament ds. Wiadomości, Akta dotyczące sposobów podnoszenia znaczenia Niemiec w Polsce, k. 3357. Niektóre dane zostały uzupełnione za pomocą curriculum vitae Seiftera, napisanego w maju 1916 roku i znajdującego się w Archiwum Uniwersytetu Wiedeńskiego.

${ }^{14}$ APUSZ, R 121308, Konsulat Generalny w Katowicach do USZ, 14 IV 1927, podpisano (z. up.) [Friedricha] Illgena; zob. też informacja o dwóch artykułach Seiftera, które ukazały się w gdańskich gazetach i które były rzekomo bardzo korzystne dla Polski, ibidem, Konsulat Generalny w Gdańsku do USZ, 23 IV 1927, podpisano [Edmund v.] Thermann, k. 3574.

${ }^{15}$ N. Krekeler, Revisionsanspruch und geheime Ostpolitik der Weimarer Republik. Die Subventionierung der deutschen Minderheit in Polen 1919-1933, Stuttgart 1973. O stanie badań na temat Niemców w Polsce w okresie międzywojennym zob. A. S. Kotowski, Die deutsche Minderheit in Polen 1919-1939/45. Forschungsstand und desiderata, „Nordost-Archiv N. F”, t. IX (2000), s. 483-506. 
nich”, tamtejsi Żydzi wiązali się z kulturą niemiecką. Jednak już pod koniec XIX wieku nastąpił tu podział na życie żydowskie i niemieckie, Żydzi np. nie byli przyjmowani do stowarzyszeń niemieckich i tworzyli wobec tego własne stowarzyszenia ${ }^{16}$. Seifter jednak pisał w swoim exposé, że „przypadki antysemityzmu w Niemczech są odosobnione" i chciał walczyć $z$ ich nagłaśnianiem przez polsko-żydowską prasę ${ }^{17}$.

Po przejęciu władzy w Niemczech przez narodowych socjalistów, pod wpływem antysemickiej polityki coraz więcej Żydów odwróciło się od Niemiec. A jednak dopiero wtedy Seifter mógł spełnić swoje marzenie o niemiecko-żydowskim czasopiśmie. Nowo powstałe Ministerstwo ds. Oświaty Narodowej i Propagandy (Reichsministerium für Volksaufklärung und Propaganda) w Berlinie było przychylne planom Seiftera. Doradca ministerialny Hermann Demann, kierownik wydziału „obrony” w ministerstwie, obiecał mu najpierw upragnione „wsparcie ideowe” ${ }^{18}$. W zamian za to Seifter wyraził gotowość składania ministerstwu co 14 dni sprawozdania z Polski; miał współpracować z „komitetem prasowym" w Berlinie. Seifter miał nadzieję zrealizować swój pomysł żydowsko-niemieckiego tygodnika dla Polski już w lecie 1933 roku$^{19}$. Ale dopiero 16 lutego 1934 roku ukazał się w Bielsku pierwszy numer gazety zatytułowanej „Jüdische Wochenpost” („Żydowska Poczta Cotygodniowa”). Seifter wydał ją wspólnie z długoletnim głównym radcą handlowym narodowo-liberalnej „Kattowitzer Zeitung” („Gazeta Katowicka”) Fritzem Guttmannem. Już wiosną 1933 roku Guttmann wszedł w konflikt z redaktorem naczelnym „Kattowitzer Zeitung” Maksem Krullem, który nie chciał drukować rzekomo bezpodstawnych informacji na temat antysemickich ekscesów w Niemczech ${ }^{20}$.

Już kilka tygodni po ukazaniu się pierwszego numeru „Jüdische Wochenpost” niemiecki konsulat generalny w Katowicach powiadomił Urząd Spraw Zagranicznych o wynikach swojego „dochodzenia” w sprawie tej gazety. Podkreślano zwłaszcza, że jednym z wydawców jest „znany Urzędowi Spraw Zagranicznych” Fritz Seifter. Konsul Franz Quiring raportował, że „Jüdische Wochenpost” starała się do tej pory „zachować neutralną postawę w sprawie wydarzeń w Niemczech" i zwalczała przede wszystkim „antyniemiecki bojkot gospodarczy ze strony Żydów”. Konsul zwrócił uwagę na jeszcze jedną, otrzymaną „poufnie” informację, a mianowicie że gazeta ma niskie ceny ogłoszeń, a także daje gratisowe anonse. Quiring sugerował w ten sposób, że „Jüdische Wochenpost" nie może się, przynajmniej na początku, samodzielnie finansować21.

${ }^{16}$ W. Kuhn, Geschichte der deutschen Sprachinsel Bielitz (Schlesien), Würzburg 1981, s. 344 n. Zgodnie ze spisem ludności z 9 grudnia 1931 roku na pytanie o język ojczysty - które było przez wielu rozumiane także jako pytanie o narodowość - z 22332 mieszkańców 10220 podało niemiecki, 1732 - jidisz, a 543 - hebrajski. Na pytanie o religię 4430 obywateli podało natomiast judaizm - jak wielu z nich podało jako język ojczysty polski albo niemiecki, nie wynika ze statystyki; por. ibidem, s. $376 \mathrm{n}$.

${ }^{17}$ Exposé Seiftera (por. przypis nr 13).

${ }^{18}$ APUSZ, Niemiecki Konsulat Generalny w Katowicach, Akta dotyczące Polityki. Tajne, Kopia pisma Demanna do USZ, 24 VIII 1934, t. 6, arkusz 185.

${ }^{19}$ Ibidem, Kopia listu Seiftera do Demanna, 10 VIII 1933, arkusz 64 n.

${ }^{20}$ T. Kowalak, Prasa niemiecka $w$ Polsce 1918-1939. Powiazania i wptywy, Warszawa 1971, s. $285-288$, tu s. $285 \mathrm{n}$.

${ }^{21}$ APUSZ, R 82931, Dział IV, Polityka 12, Górny Śląsk, Akta dotyczące postępowania prasowego, Konsulat Generalny w Katowicach do USZ, 27 III 1934, podpisano [Franz] Quiring, arkusz 55. 
Faktycznie gazeta była finansowana przez „pewien krąg prominentnych berlińskich Żydów”, którzy chcieli „zdobyć wpływy w celu obrony przed zagraniczną propagandą kłamstwa i bojkotem gospodarki”, o czym w lipcu 1934 roku Seifter poinformował Konsulat Generalny w Katowicach. Informacjami na ten temat miał dysponować wydział „obrony” Ministerstwa Propagandy, za którego „wiedzą i zezwoleniem” Seifter wydawał „Jüdische Wochenpost”. Seifter napomykając o swojej „misji”, próbował po raz kolejny uzyskać od konsulatu generalnego wizę wielokrotnego wjazdu do Niemiec ${ }^{22}$. Ustnie poinformował ponadto konsula Wilhelma Nöldeke, że planuje, za zezwoleniem wydziału „obrony” Ministerstwa Propagandy, stworzyć wydanie specjalne „Jüdische Wochenpost” dla regionu Saary ${ }^{23}$. W październiku tego roku niemiecki Konsulat Generalny w Gdańsku poinformował Urząd Spraw Zagranicznych, że Seifter zwrócił się do Senatu miasta Gdańska z ofertą wydawania tam gazety całkowicie odmiennej niż żydowskie „Danziger Echo” („Echo Gdańska”); powoływał się przy tym na swoją „Współpracę z Ministerstwem ds. Oświaty Narodowej i Propagandy”. Wygląda na to, że Seifter przedstawiał się jako agent Ministerstwa Propagandy, któremu powierzono zadanie przeciwdziałania odrzuceniu reżimu narodowosocjalistycznego przez wspólnoty żydowsko-niemieckie poza granicami Rzeszy. Uwaga na marginesie tego pisma wskazuje, że także zajmujący się w sekrecie zadaniami propagandowymi dla Urzędu Spraw Zagranicznych dziennikarz i ekonomista Curt Poralla dobrze wiedział o działalności Seiftera ${ }^{24}$.

W Konsulacie Generalnym w Katowicach wciąż jednak traktowano Seiftera dość sceptycznie. W lipcu 1933 roku Seifter zaprezentował konsulowi generalnemu Rabanowi Grafowi Adelmannowi von Adelmannsfelden rzekomo uzgodniony z Ministerstwem Propagandy plan zaproszenia Żydów o niemieckiej orientacji narodowej z Rzeszy na polski Śląsk, żeby wpłynęli na miejscową społeczność żydowską, która „coraz bardziej odwraca się od niemieckich stowarzyszeń, teatru itp.”. Adelmann ponownie przypomniał wtedy, iż „niemieckie kręgi z Bielska mają wątpliwości co do niezawodności dr. Seiftera”, i to nie tylko z powodu utrzymywania przezeń rzekomo „bliskich kontaktów z kręgami polskimi”, ale też dlatego, że Seifter „sam jest Żydem”25. W związku z tym Vicco von Bülow-(Schwante), przewodniczący referatu „Niemcy” w Urzędzie Spraw Zagranicznych, w tajnym dokumencie poinformował katowicki konsulat generalny, że Seifter nie jest wprawdzie osobą nieznaną ministerstwu, ale też nie otrzymał „oficjalnego poparcia” dla swoich planów ${ }^{26}$. Kiedy latem 1934 roku Seifter ponownie

${ }^{22}$ APUSZ, Konsulat Generalny w Katowicach. Akta dotyczące Polityki. Tajne, Seifter do Konsulatu Generalnego w Katowicach, 31 VII 1934, t. 6, arkusz 150 n., tu 150.

${ }^{23}$ Ibidem, Konsulat Generalny w Katowicach do USZ, 8 VIII 1934, podpisano [Wilhelm] N[öldeke], arkusz 149.

${ }^{24}$ APUSZ, R 83219, dział IV, polityka 12, Gdańsk, Akta dotyczące postępowania prasowego, Konsulat Generalny w Gdańsku do USZ, 25 X 1934, podpisano [Otto v.] Radowitz. Na temat Poralla i jego roli w USZ zob. P. Fischer, Die deutsche Publizistik als Faktor der deutsch-polnischen Beziehungen 1919-1939, Wiesbaden 1991, s. 119 n.

${ }^{25}$ APUSZ, Konsulat Generalny w Katowicach (jak w przyp. 18), Konsulat Generalny w Katowicach do USZ, 1 VII 1933, podpisano [Raban Graf] A[delmann von Adelmannsfelden], arkusz 39.

${ }^{26}$ Ibidem, USZ, Referat N[iemcy] do Konsulatu Generalnego w Katowicach, 7 VIII 1933, podpisano [Vicco] v. Bülow-Schwante, arkusz 61. 
zwrócił się do konsulatu generalnego z prośbą o udzielenie wizy wielokrotnego wjazdu do Niemiec w związku ze swoją działalnością publicystyczną, Urząd Spraw Zagranicznych poprosił Ministerstwo Propagandy o informacje na temat powiązań Seiftera z ministerstwem. Hermann Demann, wtedy już doradca ministerialny, odpowiedział, że jako przewodniczący wydziału „obrony” Ministerstwa Propagandy nie miał początkowo żadnych wątpliwości co do udzielania wsparcia ideowego dla planów Seiftera, które zakładały powstanie „Jüdische Wochenpost”, ponieważ gazeta ta miała prowadzić „walkę z żydowsko-polskimi periodykami prowadzącymi nagonkę na Niemcy” i przyjęła „postawę proniemiecką”. Później jednak stanowisko „Jüdische Wochenpost” „zmieniło się łatwo do rozpoznania na niekorzyść”, tak że Demann „przestał udzielać dr. Seifterowi swojego ideowego wsparcia"27. Dlatego wydział prasowy Urzędu Spraw Zagranicznych poprosił Konsulat Generalny w Katowicach o obserwowanie działalności publicystycznej Seiftera i o przyznawanie mu tylko wiz na czas określony, gdyby „nie podniosły się głosy sprzeciwu z punktu widzenia niemieckich interesów”. Konsul generalny postanowił przeciągać wydawanie Seifterowi wizy ${ }^{28}$.

Mimo to „Jüdische Wochenpost” ukazywała się do lata 1939 roku, jej nakład wynosił jednak przypuszczalnie około 5000 egzemplarzy; gazeta była rozprowadzana nie tylko w polskiej części Śląska, ale także w graniczących z nim miejscowościach w Rzeszy i Czechosłowacji oraz w Warszawie i Łodzi. Najwidoczniej gazeta nie trzymała się stale linii, która w pierwszych wydaniach zyskała poklask Niemców. Początkowo chodziło o to, żeby „na zewnątrz” dążyć, w interesie Żydów z Rzeszy, do „uprzedmiotowienia” i „rozsądnych warunków” w relacji z narodowosocjalistycznymi Niemcami. Redakcja przeciwstawiała się bojkotowi i wyrażała nadzieję na stopniowy powrót respektowania norm państwa prawa oraz na zakończenie polityki antysemickiej przemocy. „Do wewnątrz” natomiast mówiło się o „zdesyjonizowaniu i odpolitycznieniu” gmin żydowskich w Polsce. Zamiast w syjonizmie, nazywanym „faszyzmem i nacjonalizmem”, redakcja „Jüdische Wochenpost” szukała oparcia we „wzmocnionej religijności i kompletnym wcieleniu Żydów w organizmy ich krajów rodzimych”. Rezultatem była bezkrytyczna, nadzwyczaj przychylna postawa wobec państwa polskiego i polskiego rządu² ${ }^{29}$.

Stonowana publicystyka, którą - przynajmniej na początku - Seifter uprawiał w „Jüdische Wochenblatt”, odpowiadała interesom narodowosocjalistycznego rządu. Adolf Hitler już wiosną 1933 roku dążył do zmiany w tradycyjnie wrogich stosunkach między Polską a Rzeszą. Według taktycznych kalkulacji Hitlera, autorytarna Polska, rządzona przez Piłsudskiego, miała się stać uległym „niższym partnerem” w jego planach ekspansji na Związek Radziecki. Wyrazem tego zbliżenia było podpisanie

${ }^{27}$ Ibidem, Kopia pisma Demanna skierowanego do USZ, 24 VIII 1934.

${ }^{28}$ Ibidem, USZ, Departament Prasowy, dla Konsulatu Generalnego w Katowicach, 12 IX 1934, podpisano [Wilhelm] Crull, z odręcznym dopiskiem, 17 IX [1934], podpisano [Albrecht v.] K[essel], arkusz 184.

${ }^{29}$ Cyt. za: Unsere Einstellung zum antideutschen Wirtschaftsboykott oraz Neue Männer, neues Leben in der Bielitzer Kulturgemeinde, „Jüdische Wochenpost” 16 marca 1934, nr 5, s. 1 n. i 5. To wydanie „Wochenpost” było załączone do pisma Konsulatu Generalnego w Katowicach (zob. przypis nr 21). Na temat dalszego rozwoju „Wochenpost” zob. T. Kowalak, op. cit., s. 287 n. 
w styczniu 1934 roku w Berlinie niemiecko-polskiej deklaracji o nieagresji ${ }^{30}$. W związku z tym oba rządy zawarły w lutym 1934 roku układ o „współpracy w kształtowaniu opinii publicznej”, w którym stronę niemiecką reprezentowały zarówno Ministerstwo Propagandy, jak i Urząd Spraw Zagranicznych. Układ ten, który poza prasą dotyczył także wszystkich innych mediów, miał - zgodnie z oficjalną informacją - zapewniać „przyjazną atmosferę” w stosunkach polsko-niemieckich ${ }^{31}$. Jak pokazuje poufny polski dokument, Niemcom chodziło przede wszystkim o „uważną obserwację żydowskiej prasy” w Polsce, aby osłabić ruch bojkotu i nasiloną „antyniemiecką propagandę"32. Właśnie tym zamiarom odpowiadała linia „Jüdische Wochenpost”, tak że jasne staje się, w jakim celu władze niemieckie, przynajmniej na początku, wywierały za pośrednictwem Seiftera wpływ na wymowę polityczną tej gazety.

Nie jest jasne, jak długo Seifter utrzymywał kontakty z niemieckim rządem ${ }^{33}$. Wydaje się, że na przełomie lat 1939 i 1940, kiedy niemiecka administracja cywilna w zajętej Polsce zaczynała po zlikwidowaniu przedwojennej prasy tworzyć własny system przekazu informacji, nić łącząca ją z Seifterem wydawała się już zerwana. W każdym razie dopiero wiosną 1940 roku udało się Departamentowi ds. Oświaty Narodowej i Propagandy urzędu Generalnego Gubernatora „dzięki gruntownemu dochodzeniu i dociekaniu" odnaleźć Seiftera, który miał być odpowiednim redaktorem naczelnym dla planowanej żydowskiej gazety. W sprawozdaniu wewnętrznym Urzędu Propagandy o wcześniejszych kontaktach z Seifterem nie wspomniano ani słowem. Podano natomiast jeszcze jeden, obok „przyjaznych Niemcom działań”, rozstrzygający powód, dla którego akurat ten żydowski dziennikarz może być „przy pilnym nadzorze” uznany za „godnego zaufania”: były przewodniczący „Jungdeutsche Partei für Polen” (Partia Młodoniemiecka w Polsce) Rudolf Wiesner „szczerze polecił” Seiftera ${ }^{34}$.

${ }^{30}$ Günter Wollstein (Hitlers gescheitertes Projekt einer Juniorpartnerschaft Polens, „Universitas” 1983, nr 38, s. 525-532) przedstawia najbardziej szczegółową prezentację tego pomysłu. Na temat reakcji polskich władz na hitlerowską politykę wobec Polaków zob. T. Serwatka, Józef Piłsudski a Niemcy, Wrocław 1997, s. 129-163.

${ }^{31}$ Deutsch-polnische Zusammenarbeit in der öffentlichen Meinungsbildung, „Völkischer Beobachter" 28 lutego 1934, nr 59 (wydanie północnoniemieckie). Na temat realizacji tej umowy przez stronę niemiecką zob. C. Roschke, Der umworbene „Urfeind”. Polen in der nationalsozialistischen Propaganda 1934-1939, Marburg 2000, zob. też W. Wrzesiński, Sąsiad. Czy wróg? Ze studiów nad kształtowaniem obrazu Niemca w Polsce w latach 1795-1939, Wrocław 1992, s. 609-672; M. Pietrzak, Reglamentacja wolności prasy w Polsce (1918-1939), Warszawa 1963, s. 448-472.

${ }^{32}$ Notatka departamentu prasowego polskiego Ministerstwa Spraw Zagranicznych wydrukowana 23 X 1935 przez Eugeniusza Rudzińskiego, Dokumenty o porozumieniu prasowym polsko-niemieckim z 1934 roku, „Rocznik Czasopiśmiennictwa Polskiego” 1964 (4), s. 171-178, tu s. 171-175. Na temat bojkotowania narodowego socjalizmu w Niemczech zob. Y. Weiss, Deutsche und polnische Juden vor dem Holocaust. Jüdische Identität zwischen Staatsbürgerschaft und Ethnizität 1933-1940, München 2000, s. 169-194. Aby osłabić ruch bojkotu, naziści posługiwali się także żydowskimi emisariuszami z Rzeszy do Polski (ibidem, s. 173).

${ }^{33}$ Zmniejszył się obszar, a - w połowie 1935 roku - także frekwencja ukazywania się „Jüdische Wochenpost” (T. Kowalak, op. cit., s. 288). Mogłoby to wskazywać na zmniejszające się poparcie oraz częściowo na jego brak.

34 [Emil] Gassner, Jüdische Presse, w: Grundlage und Aufgaben des Propagandaamtes, [Kraków 1940], s. $120-122$, tu s. 120 . Dokument jest hektograficznie powielonym bilansem pracy Departamentu 
Informacja o stosunkach Seiftera z Rudolfem Wiesnerem może wyjaśnić, dlaczego Seifter źle ocenił zagrożenie ze strony narodowych socjalistów. Wiesner, inżynier budowlany, założył w 1921 roku w Bielsku Niemieckie Stowarzyszenie Narodowych Socjalistów w Polsce (Deutscher Nationalsozialistischer Verein für Polen), które przez dłuższy czas nie miało dużego związku z popierającymi Hitlera narodowymi socjalistami. Na początku o wiele bliższe kontakty ta mała, licząca tylko niewielu członków organizacja miała z podzielającymi ich światopogląd stowarzyszeniami z Czechosłowacji. Później chciała także współpracować z Deutsche Partei, zjednoczeniem sił narodowo-liberalnych i niemiecko-narodowych w byłej austriackiej części Śląska. Ugrupowanie to weszło więc w poczet nacjonalistycznych ugrupowań mniejszości niemieckiej w Polsce. Charakter organizacji Wiesnera zmienił się dopiero na początku lat 30., pod wpływem wzrostu znaczenia NSDAP w Rzeszy. Wtedy organizacja ta, ze względu na pogłębiający się brak zaufania władz polskich, przyjęła nazwę Jungdeutsche Partei für Polen, jednocześnie jednak zaczęła brać przykład z NSDAP i prowadzić ożywioną propagandę. Wykorzystując ich polemikę z tzw. starymi siłami politycznymi niemieckiej mniejszości udało się Partii Młodoniemieckiej zapuścić korzenie w całej Polsce. Szczególnie po dojściu NSDAP do władzy w Rzeszy, kiedy także i inni niemieccy politycy mniejszościowi starali się zbliżyć do ideologii nowego rządu w Berlinie, Wiesner i jego towarzysze partyjni podawali się za jedynych autentycznych narodowych socjalistów w Polsce. Rzeczywiście „Jungdeutsche Partei” była o wiele mniej zależna od Rzeszy niż inne, wysoko subwencjonowane niemieckie organizacje mniejszościowe. Partia ta mogła więc, nawet po 1933 roku, zachować dużą samodzielność i kwestionować polecenia z Berlina. Stosunek Wiesnera do Żydów był w dużej mierze ambiwalentny. $Z$ jednej strony, niektóre organy jego partii od początku głosiły antysemickie hasła, z drugiej jednak Wiesner osobiście współpracował, i to po roku 1933, z prominentnymi bielskimi Żydami ${ }^{35}$. Także jedna z głównych zasad programowych „Jungdeutsche Partei” głosiła: „odrzucamy wszelką wspólnotę z Żydami”, ale w uzupełnieniu dodano, że w sprawach mniejszościowych nie należy wykluczać współpracy

ds. Oświaty Narodowej i Propagandy w pierwszych dziesięciu miesiącach jego istnienia. Max du Prel, przewodniczący tego departamentu, nakazał stworzenie tego bilansu przed swoim wyjazdem z Krakowa w lipcu 1940 roku. Używany przeze mnie, prawdopodobnie jedyny, egzemplarz znajduje się w Bibliotece Jagiellońskiej w Krakowie (sygn. BJ 794541 III, 443). Na temat badań dotyczących polityki prasowej zarządu niemieckiego w Polsce zob. K.-P. Friedrich, Die deutsche polnischsprachige Presse im Generalgouvernement (1939-1945). NS-Propaganda für die polnische Bevölkerung, „Publizistik” 2001 (46), s. 162-188.

${ }^{35}$ Por. M. Cygański, Hitlerowskie organizacje dywersyjne w województwie śląskim 1931-1936, Katowice 1971, s. 45-86, szczególnie s. 50 n. Na temat Wiesnera zob. M. O. Balling, Von Reval bis Bukarest. Statistisch-Biografisches Handbuch der Parlamentarier der deutschen Minderheiten in Ostmittelund Südosteuropa 1919-1945, t. 1, Kopenhaga 1991, s. 200 n.; R. Kaczmarek, Rudolf Wiesner - przywódca górnośląskich nazistów, w: D. Kisielewicz, L. Rubisz (red.), Śląsk w myśli politycznej i dziatalności Polaków i Niemców w XX wieku, cz. 2, Opole 2004, s. 195-210. Na temat relatywnej niezależności Wiesnera i jego partii od rządu Rzeszy i związanych z tym konfliktów zob. R. Blanke, Orphans of Versailles. The Germans in Western Poland 1918-1939, Lexington 1993, s. 171-182; H.-A. Jacobsen, Nationalsozialistische Aussenpolitik 1933-1938, Frankfurt am Main-Berlin 1968, s. 584-597. 
niemiecko-żydowskiej ${ }^{36}$. Wobec stosunkowo pragmatycznej postawy Wiesnera i jego partii względem Żydów w Polsce, początkowa błędna ocena polityki antysemickiej w Rzeszy przez Seiftera wydaje się nieco bardziej zrozumiała.

W 1940 roku iluzje takie były już nie do pomyślenia. „Noc kryształowa” 9 listopada 1938 roku, a jeszcze bardziej mordy i akty przemocy dokonywane przez niemieckich okupantów na Polakach i Żydach od września 1939 roku musiały otworzyć oczy także ostatnim tutejszym sympatykom Niemiec. Co ciekawe, tym razem to nie Seifter szukał kontaktu z urzędami niemieckimi, ale one same go znalazły. Nie było więc ciągłości we współpracy Seiftera z niemieckimi władzami w latach 30. a jego późniejszą działalnością jako redaktora naczelnego i kierownika „Gazety Żydowskiej”. Nie wiadomo, jakie okoliczności sprawiły, że podjął się tych zadań. Pewne jest, że Seifter nie był pod żadnym względem wolny. Gazeta, jej wydawnictwo i treść w pełni podlegały niemieckiemu nadzorowi i kontroli. Jüdische Presse GmbH (Prasa Żydowska sp. z o. o.) była nadzorowana przez filię głównego wydawnictwa NSDAP i trzymana „możliwie krótko"; każde wydanie gazety podlegało rygorystycznej cenzurze ${ }^{37}$.

Oficjalnie podane zadania i cele tej gazety odpowiadały tylko częściowo stanowisku, które w swoim czasie zajmowała „Jüdische Wochenpost”: żydowska gazeta w Generalnym Gubernatorstwie miała być gazetą, jak wspomniano już na wstępie zacytowanej zapowiedzi, „która będzie się zajmować wewnątrzżydowskimi sprawami, podobnie jak prasa żydowska ukazująca się w protektoracie czesko-morawskim i w Rzeszy. Gazeta ta chce szczególnie pielęgnować ideę produktywizacji Żydów, ich przewarstwowienia i przeszkolenia, chce też zająć się problemem emigracji i wszystkimi innymi społecznymi i religijnymi problemami, które dotykają Żydów"38. Koncentracja przede wszystkim na kwestiach żydowskich, na problemach społecznych, ekonomicznych oraz religijnych była wspólnym celem „Gazety Żydowskiej” i własnych wizji Seiftera. Nowe były apele o pracę i (iluzoryczne) perspektywy emigracji Żydów z Polski. Interesy niemieckich władz okupacyjnych ze współpracującymi z nimi Żydami pokrywały się jeszcze wtedy w tych dwóch zagadnieniach. Faktycznie byli jeszcze po obu stronach ludzie, którzy w zaangażowaniu Żydów w niemiecką gospodarkę wojenną Generalnego Gubernatorstwa z perspektywą emigracji po szybko wygranej wojnie widzieli możliwość krótkotrwałego modus vivendi pomiędzy ludnością żydowską a okupantami. Na początku nie było mowy o tym, że niemiecka „polityka żydowska” będzie prowadziła do mordowania Żydów ${ }^{39}$.

${ }^{36}$ Unsere Leitsätze. Erläuterungen zu den weltanschaulichen Grundgedanken der Jungdeutschen Partei für Polen, wyd. 4, Bielsko 1934, s. 23 n.

37 [Emil] Gassner, op. cit., s. 120. Problem cenzury był jednym z powodów, dla których gazeta ukazywała się w języku polskim, a nie w jidisz. W krakowskiej Bibliotece Jagiellońskiej zachował się segregator z odbitkami korektorskimi „GŻ”; por. Korekta „Gazety Żydowskiej” rok 1941, BJ 794541 III, 444 (Oznaczenie to jest eufemistyczne: odbitki korektorskie zawierają skreślenia i są zaopatrzone w odręcznie napisaną notatkę: „dop[uszczone]”).

${ }^{38}$ Eine jüdische Zeitung im Generalgouvernement, „Krakauer Zeitung”, 17 lipca 1940, nr 167.

${ }^{39} \mathrm{Na}$ temat polityki niemieckiej wobec ludności żydowskiej w Generalnym Gubernatorstwie do czasu jej systematycznego unicestwiania zob. Ch. Browning, Die Entfesselung der „Endlösung”. Nationalsozialistische Judenpolitik 1939-1942, Monachium 2003, s. 30-252. Zob. też D. Pohl, Die 
Kolejnego ważnego celu, który niemieccy propagandyści z Generalnego Gubernatorstwa łączyli z „Gazetą Żydowską”, nie wymienili publicznie, chociaż łatwo go było wywnioskować: własna żydowska gazeta miała, obok postępującego podziału terytorialnego miedzy Żydami a Polakami, wspierać także emocjonalną dysymilację. Fakt, że „Gazeta Żydowska” ukazywała się w języku polskim, tylko pozornie przeczył temu zamiarowi, ponieważ miała ona dotrzeć do właśnie tych dominujących, częściowo zasymilowanych z Polakami kręgów żydowskich ${ }^{40}$. Szef krakowskiego Departamentu do spraw Oświaty Narodowej i Propagandy, Max du Prel, mówił, żeby w propagandzie dla Polaków i Żydów „być jednocześnie anty- i prożydowskim, tak długo jak w Generalnym Gubernatorstwie znajdują się jeszcze Żydzi”41.

Chociaż władze okupacyjne zabroniły od maja 1941 roku dystrybucji prasy przeznaczonej dla Niemców i Polaków w warszawskim getcie, także takie gazety dostawały się do getta, gdzie sprzedawano je po cenach czarnorynkowych. Poza tym w getcie prowadzono ożywioną publicystykę konspiracyjną, która mogła być jednak rozpowszechniana jedynie $\mathrm{w}$ niewielu egzemplarzach i w zaufanych kręgach. Zarówno przedstawiciele żydowskiego podziemia, jak i środowiska Judenratu oraz służby porządkowej mieli „Gazetę Żydowską” i jej pracowników w pogardzie - ich zdaniem gazeta okupacyjna prawie nie była czytana i „żaden przyzwoity dziennikarz” dla niej nie pracował $^{42}$.

Zupełnie inny obraz przedstawiła w swoim dzienniku Mary Berg, córka polskiego Żyda i Amerykanki z USA, która jako młoda dziewczyna znajdowała się w getcie. W swoich wspomnieniach podkreślała ona, że „Gazeta Żydowska” była jedynym łącznikiem pomiędzy różnymi gettami w Polsce. Szczególnie pożądanym materiałem prasowym były sprawozdania z działalności poszczególnych rad żydowskich ${ }^{43}$. Każdy, jak

Ermordung der Juden im Generalgouvernement, w: U. Herbert (red.), Nationalsozialistische Vernichtungspolitik 1939-1945. Neue Forschungen und Kontroversen, Frankfurt am Main 1998, s. 98-121.

40 [Emil] Gassner, op. cit., s. 120. Por. poza cytowaną na początku oceną „GŻ” u Landaua, Kronika, s. 589 oraz tamże s. 613 (wpis z 30 czerwca 1940 roku).

${ }^{41}$ M. du Prel, wstęp w: Grundlage, s. I-XIX, tu s. VIII. Ukazywanie się „GŻ” faktycznie wywołało zamieszanie w polskim podziemiu i na wygnaniu: twierdzili, że ich stylistyka jest lepsza niż przeznaczonych dla Polaków gazet okupacyjnych; por. K.-P. Friedrich, op. cit., s. 168.

${ }^{42}$ E. Ringelblum, op. cit., s. 314 i 372 n. (wpisy z lipca-września 1941 oraz 12 maja 1942 roku). Por. też Dziennik Adama Czerniakowa..., s. 133 (wpis z 23 czerwca 1940 roku) oraz S. Adler, In the Warsaw Ghetto. 1940-1943. An Account of a Witness, Jerusalem 1982, s. 261 n. Adler był oficerem Służby Porządkowej utworzonej przez władze okupacyjne. Na temat polityki warszawskiego Judenratu i jego przewodniczących: M. Fuks, Das Problem der Judenräte und Adam Czerniaków Amtstätigkeit, w: S. Jersch-Wenzel (red.), „Deutsche - Polen - Juden. Ihre Beziehungen von den Anfängen bis ins 20. Jahrhundert”, Berlin 1987, s. 229-239; na temat Służby Porządkowej zob. I. Trunk, op. cit., s. 475-569.

${ }^{43}$ S. L. Shneiderman (wyd.), Warsaw Ghetto. A diary by Mary Berg [Miriam Wittenberg], New York 1945, s. 66 n. (wpis z 10 czerwca 1941 roku). Sprawozdania z działalności Judenratów zob. M. Fuks, op. cit.; istotnie, np. dziennik zdecydowanego przeciwnika współpracy z władzami okupacyjnymi pokazuje, że nawet on używał „GŻ” (podobnie jak innych niemiecko- i polskojęzycznych gazet wydawanych przez okupanta), szczególnie do zdobywania informacji na temat sytuacji we wspólnotach żydowskich; por. A. I. Katsch (wyd.), The Warsaw Diary of Chaim A. Kaplan, wyd. 2, New York 1973, s. 63 n., 173 n., 176 n., 182, 207, 265, 304 i 360 (wpisy z listopada 1939-czerwca 1942 roku). 
najszybciej przekazywany dalej, egzemplarz „Gazety Żydowskiej” miałby setki czytelników, także ze względu na ograniczony nakład ${ }^{44}$. Faktycznie gazeta reklamowała się za pomocą następującego ogłoszenia: „Dlaczego każdy Żyd powinien być abonentem »Gazety Żydowskiej«? Ponieważ jedynie ona jest pomostem między nim a pozostałym światem żydowskim" 45 .

Dopiero po podjęciu decyzji o eksterminacji i rozpoczęciu deportacji Żydów do obozów zagłady Niemcy uznali, że mogą zrezygnować z żydowskiej gazety. Latem 1942 roku „Gazeta Żydowska” przestała się ukazywać ${ }^{46}$. Dalsze losy jej redaktora naczelnego i kierownika nie są znane. Może został on już w październiku tego samego roku deportowany do Bełżca, może dostał się - jak inni Żydzi pełniący ważniejsze funkcje $\mathrm{w}$ krakowskim getcie ${ }^{47}$ - dopiero $\mathrm{w}$ następnym roku do położonego nieopodal obozu w Płaszowie.

Co należy zapamiętać o Fritzu Seifterze i jego współpracy z władzami niemieckimi? Wracając do wspomnianej we wstępie dyskusji na temat żydowskiej „kooperacji” albo „kolaboracji” z narodowymi socjalistami: nie ma wątpliwości, że Seifter - przynajmniej w latach 1933 i 1934 - służył Ministerstwu Propagandy jako wpływowy agent-publicysta działający wśród niemieckojęzycznych Żydów w Polsce - ale czy przez to stał się w 1940 roku kolaborantem w Generalnym Gubernatorstwie? Okoliczności jego współpracy w 1933-1934 były zupełnie inne niż latem 1940 roku. Wydawało się, że w pierwszych latach rządów narodowych socjalistów po obu stronach istniała jeszcze częściowa zgodność politycznych interesów i idei. Naziści wydawali się początkowo przedstawicielami niemieckiego nacjonalizmu, z którym Seifter sympatyzował, ich brutalny antysemityzm byłby jeszcze możliwy do złagodzenia. W 1940 roku natomiast Seifterowi i Żydom w Polsce chodziło już tylko o przetrwanie w reżimie, który nie okazywał wobec Żydów żadnej litości. W takich okolicznościach oceniające pojęcie „kolaboracji” nie jest na miejscu, ponieważ absolutny priorytet przetrwania pozbawił mocy obowiązującej zwyczajne mierniki wartości. W tym sensie działalność Seiftera dla „Gazety

${ }^{44}$ Ze względu na brak papieru władze okupacyjne już w kwietniu 1941 roku ograniczyły nakład „Nowego Kuriera Warszawskiego”, swojej gazety przeznaczonej dla ludności polskiej Warszawy, zob. K. Dunin-Wąsowicz i in. (red.), Raporty Ludwika Fischera, Gubernatora Dystryktu Warszawskiego 1939-1944, Warszawa 1987, s. 318.

45 To ogłoszenie pojawiło się np. w „GŻ” 21 marca 1941, nr 23, s. 4.

${ }^{46}$ Prawdopodobnie ostatnie wydanie „GŻ” ukazało się 30 sierpnia 1942 roku; por. T. Cieślak, op. cit., s. 579; S. Adler, op. cit., s. 262; M. Fuks, Judenraty, s. 169, inne źródła podają, że gazeta ukazywała się tylko do połowy lipca 1942 roku. Z początkiem maja we wszystkich dystryktach Generalnego Gubernatorstwa zaczęły się przygotowania do opróżnienia gett i deportacji ich mieszkańców do obozów zagłady, por. D. Pohl, op. cit., s. 105.

${ }^{47}$ Po zamordowaniu i deportacji ostatnich większych grup Żydów w marcu 1943 roku zostało w krakowskim getcie już podobno tylko około 50 rodzin członków Judenratu i żydowskiej służby porządkowej, które zostały pod koniec roku 1943 deportowane albo na miejscu zamordowane; zob. A. Bieberstein, Zagłada Żydów w Krakowie, Kraków 1985, s. 82-94. Okoliczności śmierci Seiftera nie są znane. Sporządzona przez jerozolimski Instytut Yad Vashem baza danych o ofiarach Shoah (znanych jest dotąd około 3 mln nazwisk), nie wspomina Friedricha Seiftera, por. The Central Database of Shoah Victims" Names (Centralna Baza Danych o Nazwiskach Ofiar Shoah), http://www.yadvashem.org (dane z dn. 27 października 2005). 
Żydowskiej” wydaje mi się jedną z wielu - nie skierowanych wprost na własną osobę, ale także na całokształt społeczności żydowskiej - strategii przetrwania, które w tragicznym końcu okazały się beznadziejne ${ }^{48}$.

[z niemieckiego przełożył Mirostaw Wasilewski]

\title{
Słowa kluczowe
}

Friedrich Seifter, stosunki polsko-niemieckie, stosunki niemiecko-żydowskie, prasa codzienna, propaganda, narodowy socjalizm, okupacja, kolaboracja

\begin{abstract}
Fritz Seifter, a Jewish-German journalist and Polish citizen, collaborated with the German authorities on two occasions: first during 1933-1934 in Bielsko, where, supported by the Reich Ministry of National Education and Propaganda, he launched his newspaper Jüdische Wochenpost; second, in July 1940, when the General Governor's Department of National Education and Propaganda in Cracow appointed him editor-in-chief and managing director of Gazeta Żydowska. But in either case the circumstances and motives for collaboration differed significantly.

In the case of Jüdische Wochenpost, Seifter completed a project he had been planning to carry out since the late 1920s. His newspaper was to consolidate the bonds of German-speaking Polish Jews with Germany. The Reich Ministry of National Education and Propaganda supported the establishment of this newspaper in order to tone down the opinions of Polish Jews regarding the Nazi regime in Berlin. During 1933-1934 Seifter saw himself as an agent of the German Ministry of Propaganda.

In 1940, German occupation authorities in Krakow searched for and found Fritz Seifter, who was to be appointed editor-in-chief and managing director for the Germanplanned Gazeta Żydowska, completely controlled by the Germans. Its principal aims were to isolate the Jews even further from their Polish environment, herd them to work and give illusions of hope for emigration after the war.

Thus there was no continuity in Seifter's co-operation with the German authorities, and collaboration was not the case. During 1933-1934, Seifter's main reason to launch his newspaper was German nationalism, which ostensibly linked him to the Germans. In 1940, however, Fritz Seifter no longer acted of his own accord, and any illusions as to the genocidal character of the Nazi regime was out of the question: Seifter alongside the rest of Polish Jews wanted only to survive.
\end{abstract}

\section{Key words}

Friedrich Seifter, Polish-German relations, German-Jewish relations, newspaper, propaganda, national socialism, occupation, collaboration

${ }^{48}$ Por. T. Grosse, Przeżyć! Obrona życia jako wartość podstawowa społeczności getta warszawskiego, Warszawa 1988; D. Diner, Die Perspektive des „Judenrats”. Zur universellen Bedeutung einer partikularen Erfahrung, w: D. Kiesel i in. (red.), „Wer zum Leben, wer zum Tod...”. Strategien jüdischen Überlebens im Ghetto, Frankfurt am Main-New York 1922, s. 11-35. 